\title{
Trailing the Gap between the Competencies of Bachelor of Science in Business Administration Graduates with Industry Demands: As Viewed by the Employers
}

\author{
Clarizza L. De Leon, Jennilyn C. Mina, Edgelly G. Vitug, Noemi C. Vega, Joannie A. Galano, \\ Rosenell B. Flores, Emery Caymo, Kaila Beatrice Magtalas
}

CMBT, Nueva Ecija University of Science and Technology, San Isidro, Philippines

Email: clrzdeleon@yahoo.com,zedka_jen27@yahoo.com, edgellyvitug14@gmail.com,noemi.vega930@gmail.com, jag.pm77@yahoo.com,rsnllflrs14@gmail.com, emerylei25@gmail.com, aliakmagtalas@gmail.com

How to cite this paper: De Leon, C.L., Mina, J.C., Vitug, E.G., Vega, N.C., Galano, J.A., Flores, R.B., Caymo, E. and Magtalas, K.B. (2021) Trailing the Gap between the Competencies of Bachelor of Science in Business Administration Graduates with Industry Demands: As Viewed by the Employers. Open Access Library Journal, 8: e8193.

https://doi.org/10.4236/oalib.1108193

Received: November 15, 2021

Accepted: December 12, 2021

Published: December 15, 2021

Copyright $\odot 2021$ by author(s) and Open Access Library Inc.

This work is licensed under the Creative Commons Attribution International License (CC BY 4.0).

http://creativecommons.org/licenses/by/4.0/ (c) (i) Open Access

\begin{abstract}
Employees are increasingly seen as a company's greatest asset. As a result, educational institutions must ensure that their curricula are in line with society's demands and needs. A university's ability to produce high-quality graduates based on the market demands can be assessed by the feedback that institutions obtain from the employers of the alumni. Besides, this assessment can be considered as the greatest approach to gauge the efficiency of the programs and the marketability of their graduates. Thus, this research aims to assess the performance of the 2019 and 2020 Business Administration Major in Marketing Management graduates of the Nueva Ecija University of Science and Technology-Tabon Annex as observed by their current employers. To assess the employer's feedback on the performance of the graduates, the researchers employed a descriptive research method and the data gathered were interpreted using the frequency, percentage distribution, and weighted mean. The results gathered were established with the use of a survey questionnaire that was administered through the use of digital platforms. This study used two (2) sets of questionnaires: one for the graduates to describe their current employment situation, and the other for their current employers or immediate supervisors to assess their performance. The findings showed that the majority of recent graduates were employed and had been with their present employers for over a year at the time of the conduct of this research. More than half of the employed are regular workers and almost all of them are rank and file employees. Results of the survey revealed an exceptional rating from the employers in terms of work attitude, communication skills, numerical
\end{abstract}


competency, information technology literacy, interpersonal skills, record keeping skills, and technical skills. Favorably, the employers positively evaluated the competencies of the graduates in terms of the Program's Educational Objectives. Overall, there is no doubt that the graduates met or surpassed the organizations' expectations in almost every quality demanded by the workforce. Hence, the researchers proposed that the university focus on combining educational training with industry and market demands. Furthermore, it is recommended that the business administration graduates should not be limited to functioning as employees; instead, they should be exposed to a variety of entrepreneurial activities. Lastly, the university should deliberate about revisiting, revising, and expanding the course curriculum to better prepare its future graduates for the real battlefield after graduation.

\section{Subject Areas}

Marketing

\section{Keywords}

Employer's Feedback, Marketing Management, Program Educational Objectives, Skills

\section{Introduction}

The employees are the true asset of an organization. Thus, investing in people is critical and essential for the economic and social development of any country (Ranasinghe \& Herath, 2011) [1]. Pasban and Nojedeh (2016) [2] stated that the accumulation of knowledge and human capital directly affects efficiency. Accordingly, education has traditionally been linked to economic success. Suarez et al. (2018) [3] solidified this claim by pointing out that education plays a key role in developing any country. To this end, educational reforms have been tied to economic growth in the context of the Philippines.

Furthermore, higher education is at the top of the education pyramid and determines to a large extent the state of the education system of the country, especially its quality. As such, it has a responsibility towards the whole education system and, therefore, towards primary education (Sanyal, 2012) [4]. The goal of the higher education system of the Philippines is to develop professionally competent, service-oriented, principled, and productive citizens (Mananita, 2020) [5]. Higher education institutions have a legal obligation to prepare students for employment by expanding their chosen disciplines' competencies. In line with the thrusts of the Philippine Development Plan 2017-2022 [6] and as articulated in the Commission on Higher Education (CHED) Strategic Plan, reforms in higher education are aimed at maximizing the system's contribution towards developing competent and high-level human resources and generating knowledge and technologies needed for advancing the graduate's competitiveness. 
The commission has emphasized that the quality of higher and technical education will be improved to produce competent and highly nimble individuals and workforce. Policies and programs will be put in place to increase the income-earning ability of individuals. These include apprenticeship and internship programs, opportunities for re-tooling and skills enhancement, and policies to promote work-life balance and ensure that workers receive decent wages.

In relation to this, Plantilla (2017) [7] claimed that the effectiveness of an educational program offered by an educational institution could be measured through the competencies of its graduates, the knowledge and skills acquired that can be applied in the work environment. In the report presented by The Institutional Management in Higher Education (2012) [8], it was stated that the fundamental changes in employment over the past 50 years imply a rise in the demand for non-routine cognitive and interpersonal skills. Moreover, graduates are entering a world of employment characterized by more significant uncertainty, speed, risk, complexity, and interdisciplinary working. The study of Ramirez et al. (2014) [9] noted that the graduates claimed their knowledge, academically acquired skills, and competencies contributed significantly to their job performance.

The real measure of how well the educational programs are best implemented is through the feedback the university gets from the employers of its graduates (Navarro, 2020) [10]. Employers are considered one of the important stakeholders of higher education institutions who give more meaning and value to the knowledge, skills, and attitude of the graduates (Encio et al., 2016) [11]. In the corporate world, creativity and innovations occur rapidly due to the dynamic nature of the business environment. Various organizations are concentrating on their core competencies to provide flexibility and improved organizational performance and ensure the efficient use of key resources (Al-Kassem, 2017) [12]. Employers are searching for more in their business management employees in today's competitive market: more know-how, competencies, and potential. This can be supported by the study conducted by Burning Glass Technology (2015) [13] where it listed some of the specialized business management skills employers desire when searching for employees. These include knowledge in administration, budget management, conflict management, delegation, financial data interpretation, and legal statutes relevant to the business.

With the constant shift in the expectations of a changing society, numerous listings show that some employers complain about the insufficiency of skills among the workers. Based on the report conducted by Mourshed et al. (2012) [14], only 42 percent of employers believe their pre-hire education adequately prepared their recent hires for an entry-level position. Similarly, only 45 percent of youth felt adequately prepared for an entry-level position in their chosen career field. Given this level of disconnect, it is critical for the country's educational system to develop solutions to meet these needs. A market-driven educational system is now required to create graduates prepared for work and have acquired 
the requisite characteristics to function as productive and responsible citizens. Universities must integrate fundamental generic skills required by companies and successfully integrate work into coursework to produce work-ready graduates.

As a higher education institution, the Nueva Ecija University of Science and Technology (NEUST) is obliged to prepare students for the world of employment, generate competent and worthy graduates, and develop a future professional workforce with a high level of knowledge and skills required by industry. Hence, the central theme of the study was to investigate how graduates performed in a real-world job environment from the perspective of employers. Additionally, the researchers sought to ascertain the graduates' competencies concerning the program's educational objectives and the reasons for graduates' unemployment or self-employment. The findings were beneficial in identifying gaps between the quality of skills acquired by business graduates and the requirements of employers, which would serve as a significant lean in aligning the institution's human capital development efforts with industry demands. Finally, it provided valuable insights and input into educators' teaching methodologies to raise the quality of education.

\section{Objectives of the Study}

This study assessed the performance of the graduates of Business Administration-Marketing Management of the Nueva Ecija University of Science and Technology San Isidro Campus as observed by their current employers. Specifically, this research endeavor sought to achieve the following objectives:

1) To describe the employment profile of the business administration graduates in terms of:

- Year graduated;

- Types of employment status;

- Number of years in service in the present organization;

- Types of employment in the present organization; and

- Position in the present organization.

2) To describe the business administration graduates' performance based on the assessment of their current employers in terms of:

- Work attitude;

- Communication skills;

- Numerical competency;

- Interpersonal skills;

- Recordkeeping skills; and

- Technical skills.

3) To determine the competencies acquired by the graduates in relation to the program educational objectives.

4) To identify the employers' likelihood of hiring business administration graduates from NEUST. 


\section{Methodology}

The researchers used a descriptive research method that describes and interprets the data and characteristics of what is being studied. Cooper and Schindler (2011) [15] stated that a descriptive study tries to discover answers to the questions what, who, where, when, and sometimes how. Descriptive research is often used when there is already a great deal of knowledge about the subject, and this knowledge can then be used to categorize the information into models.

The respondents of this study were the Business Administration-Marketing Management graduates of the Nueva Ecija University of Science and Technology San Isidro Campus. Moreover, to fully realize the objectives of this study, the current employers or immediate supervisors of the employed graduates were also asked to answer a survey to collect feedback on the performance of the graduates. They were considered as the most valuable source of information on the graduates' job performance. The primary data was heavily limited by the sampling procedure namely snowball sampling method. The respondents are asked to recommend other contacts who fit the research criteria and who potentially might also be willing to participate, who then, in turn, recommend other potential participants, and so on. Researchers, therefore, use the social networks to establish initial links, with sampling momentum developing from these, capturing an increasing chain of participants (Parker, 2019) [16]. The applied sampling procedure was used due to difficulty experienced in reaching out to the respondents.

In order to gather necessary data for the completion of this study, the researchers utilized a survey questionnaire to be administered through the use of digital platforms. To produce the questionnaires, the researchers reviewed relevant literature and studies that were related to the employer's feedback study. There were items included in the questionnaire that are designed to measure how well the competencies of the graduates are being observed in the working environment. In fact, there were two (2) sets of questionnaires and both were validated by the experts and other academicians in the field of Marketing Management and Partner Host Training Establishments of the university where most business administration graduates are being absorbed after their On-the-Job Training. The reliability of the questionnaire was also established by the researchers' statistician. To specify, the first instrument was intended for the graduates to describe their present employment situation or gather information on why they were unemployed or their reason for starting their own business. There were 88 graduates out of 105 who responded to the first round of questionnaires, and it was discovered that 55 of them got employed as a result of their responses.

The second instrument was purposely designed for the current employers or immediate supervisors to acquire insight into the performance of the employed graduates. A two-part questionnaire was utilized as the primary tool for data collection. The first section of the questionnaire was adapted from the study of Sannadan, Lang-ay, and Guidangen (2016) [17] to assess their performance 
attributes, which were divided into the following categories: Work Attitude, Communication Skills, Numerical Competency, Information Technology Literacy, Interpersonal Skills, Recordkeeping Skills and Technical Skills Required to do the job. The second component of the instrument described the assessments of the employers on the competencies of the graduates based on the NEUST College of Management and Business Technology's Program Educational Objectives. It also inquired about the employers' likelihood of hiring NEUST graduates. This questionnaire was completed by 26 of the employers.

The data were gathered, tallied, and recorded for statistical treatment, analysis, and interpretation. The following tools were used to analyze data in this study: Percentage, Frequency Distribution, Weighted Mean, and Thematic Analysis.

To interpret the graduates' performance attributes, they were assessed on a 4-point Likert-type rating scale as follows (Table 1).

In terms of the competencies of the graduates concerning the NEUST CMBT Program Educational Objectives (PEO), the graduates were evaluated according to the below scales (Table 2).

\section{Results and Discussion}

This section presents the findings obtained from the primary instrument used in this study. The responses were organized, quantified, and interpreted using different statistical tools. The presentation observed the sequence of the specific problems formulated for the study.

Table 1. Scale on data interpretation for graduates' performance attributes.

\begin{tabular}{ccc}
\hline Scale & Verbal Interpretation & Verbal Description \\
\hline 4 & Exceptional & Always exceeds employers required standards \\
3 & Exceed Expectations & Sometimes exceeds employers required standards \\
2 & Improvement Needed & Sometimes fails to meet employers required standards \\
1 & Unsatisfactory & Always fails to meet employers required standards \\
\hline
\end{tabular}

Table 2. Scale on data interpretation for graduates' competencies in relation to the PEO.

\begin{tabular}{ccc}
\hline Scale & Verbal Interpretation & Verbal Description \\
\hline 4 & Strongly agree & $\begin{array}{c}\text { The immediate supervisor has a } \\
\text { very positive view of the statement } \\
\text { The immediate supervisor has a } \\
\text { positive view of the statement }\end{array}$ \\
2 & Disagree & $\begin{array}{c}\text { The immediate supervisor has a } \\
\text { negative view of the statement } \\
1\end{array}$ \\
& Strongly Disagree & $\begin{array}{c}\text { The immediate supervisor has a } \\
\text { very negative view of the statement }\end{array}$ \\
\hline
\end{tabular}




\subsection{Profile of the Business Administration Graduates}

Figure 1 shows the distribution of the respondents according to the year they graduated. As indicated in the figure, $89 \%$ of the graduates who responded to this study earned their degree in 2019 . In 2020 , the remaining $11 \%$ of respondents completed their education.

The low number of graduates from 2020 was notable, as it was affected by the implementation of the K-12 Curriculum. One of the consequences of this reform was the significant impact on colleges and universities which resulted in a sharp drop in higher education enrollments during the academic year 2016 to 2018, as the batches of students who would traditionally enroll on campus continued in senior high school. As extracted on the website of the Commission of Higher Education (2017) [18], senior high school was rolled out nationwide in 2016, and students had to go through two more years of high school instead of going straight to college. De Guzman (2017) [19] affirmed that the Philippines' first-year college programs in various universities and colleges have not surprisingly suffered from the low number of enrollees between these years.

Figure 2 shows the distribution of the respondents according to the type of employment status. As shown in the figure, $60 \%$ were employed, $34 \%$ were unemployed, and $6 \%$ were self-employed.

The result showed the employability of the graduates from the Business Administration program, specifically the marketing management major. It has been clearly manifested that the curriculum was aligned with the policies, standards, and guidelines, thus, it satisfies the needs of the industry. As a result, graduates have the necessary skills and knowledge to be competitive to face the challenges of finding a job and becoming part of the workforce. A broadly accepted definition of employability is a set of achievements, skills, understandings, and personal

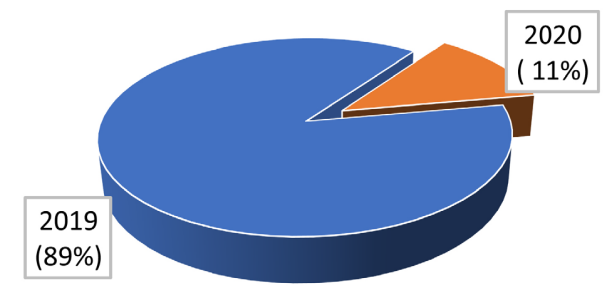

Figure 1. Year graduated.

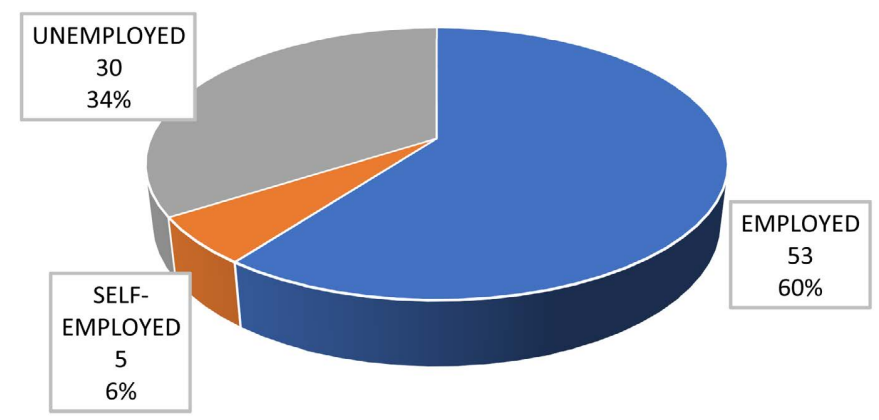

Figure 2. Type of employment status. 
attributes - that make graduates more likely to gain employment and be successful in their chosen occupations, which benefits themselves, the workforces, and the community (Dhaliwal \& Misra, 2020) [20].

Unfortunately, the findings also demonstrated that a considerable proportion of the graduates were also unemployed during the conduct of this study. Based on the survey, half of the unemployed graduates claimed that they could not find work because of the COVID-19 pandemic. Searching for a new job is extremely challenging during a coronavirus outbreak as most firms are laying off employees, and regular hiring practices have been disrupted. Based on the report of Adiyoh et al. (2020) [21], as the world struggles to combat the pandemic, countries are experiencing unprecedented economic shutdowns. Due to a reduction in production volumes and challenging market conditions, Micro, Small, and Medium Enterprises are battling to survive. The COVID-19 pandemic and subsequent hard lockdown (Enhanced Community Quarantine) has resulted in the highest unemployment rate and the most significant drop in Philippine GDP in history (Lim, 2020) [22].

Lastly, even though BSBA graduates were expected to work in the field of marketing, some chose to change their paths and pursued entrepreneurship. Respondents believe that establishing their businesses will allow them to realize their dreams and fulfill their needs by applying what they learned in the university. Entrepreneurship has been described as the capacity and willingness to develop, organize, and manage a business venture along with any of its risks to make a profit (Bhattacharjee, 2020) [23].

Figure 3 shows the distribution of the respondents according to the number of years in service for the present organization. As shown in the above data, $41 \%$ of respondents served for more than one year, followed by $38 \%$ who served for less than six months, and the remaining $21 \%$ served for between six months to one year.

The statistics suggested that the graduates could find employment shortly after graduation since they had been with their current employer for more than a year, implying that the graduates were marketable consequent with this study's result on the status of employment. This is congruent with De Leon et al. (2020)

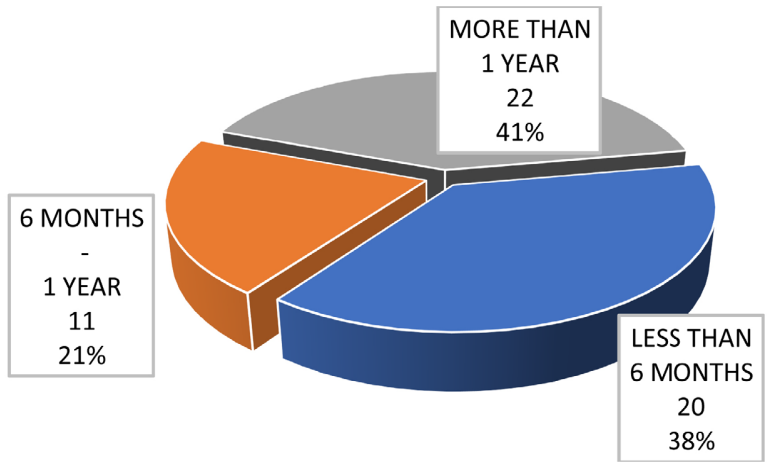

Figure 3. Number of years in service for the present organization. 
[24], who found that the employability rate of the Nueva Ecija University of Science and Technology graduates was strongly expected.

From the viewpoint of the employed graduated who participated in the survey, because of the COVID-19 pandemic, job switching during this period can be seen as a challenge. They will not risk changing unless they are certain of a positive outcome (Deluna and Berdos, 2015) [25].

Figure 4 shows the distribution of the respondents according to types of employment in the present organization. It can be illustrated from the data above that the majority, or $56 \%$ of the employed graduates, were regular, $23 \%$ were on temporary status, and $21 \%$ were casual.

Since most of the graduates were on regular status, it signifies that they could pass the qualification standards for the regularization of their respective organizations. In accordance with Article 296 of the Labor Code, a regular employee is authorized to work after completing a probationary term. The status of employment reflects the security of tenure that the graduates expect for their performance as employed. When employees complete their probationary period, they become permanent employees with strong protection from unjust employment practices by institutions (Berry, 2018) [26].

Figure 5 shows the distribution of the respondents according to their position in the present organization. As displayed in the figure above, a vast percentage of the working graduates, or $96 \%$, were rank and file, while $4 \%$ were on supervisory level.

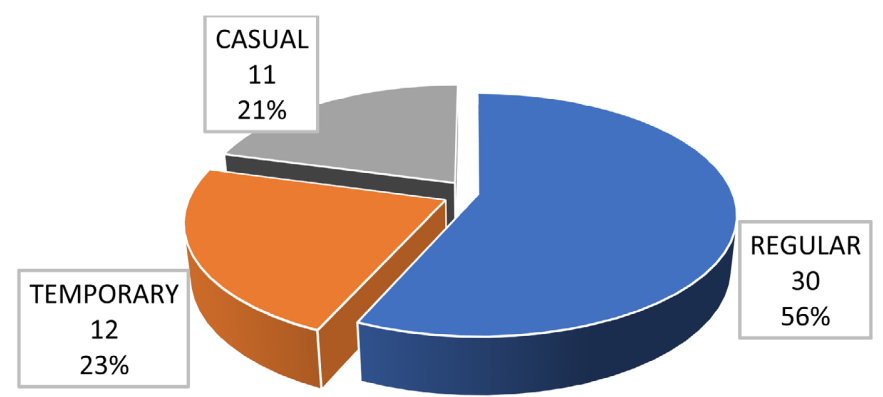

Figure 4. Types of employment in the present organization.

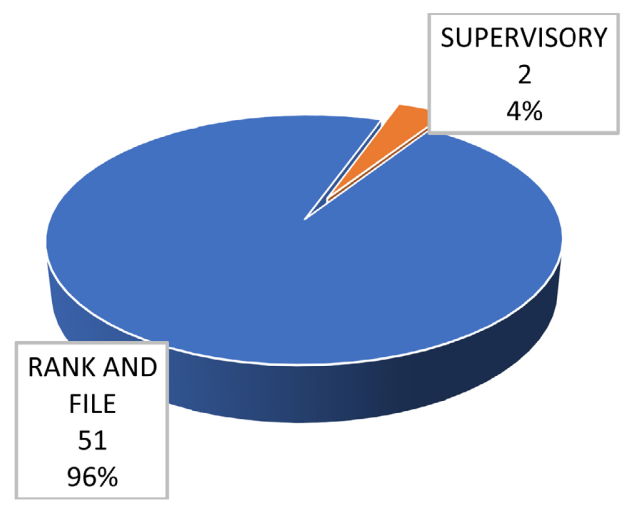

Figure 5. Position in the present organization. 
Logically, most of the respondents were on rank-and-file status because they were considered young and still needed to acquire more skills, knowledge, and experience to match the qualifications required for the higher positions. Based on the study of Vardi and Hammer (2017) [27], rates and directions of intraorganizational job mobility and perceptions of mobility requirements among the rank and file employees were found to differ by experience and knowledge.

Despite the preceding findings, it is worth mentioning that two (2) graduates have already been promoted to supervisory positions. Based on the unstructured interviews, one of the respondents who has been affiliated in a large self-service store selling foods and household goods in Nueva Ecija used to be a working student during college which made him well-equipped with both knowledge and job experience while the other respondent who is handling the supervisory level position was actually being trained in their family business since they owned the funeral services where he presently works. Claussen et al. (2014) [28] claimed that experience, expertise, and network size positively affect promotion odds.

\subsection{Employer's Feedback on the Performance of the BSBA Marketing Management Graduates}

Table 3 shows the employers' feedback on the performance of BSBA Marketing Management in terms of work attitude. As can be gleaned from the table, item 1, "Has a sense of commitment and duty", received the highest weighted mean of 3.58, which is verbally interpreted as "Exceptional". On the contrary, item 3, "Has the ability to take charge of one's engagement and empowerment", got the lowest weighted mean of 3.35, which was verbally interpreted as "Exceptional". Overall, the employers positively evaluated the performance of the BSBA Marketing Management graduates in terms of work attitude with the average weighted mean of 3.44 , which means that they always exceed employers' required standards.

Commitment is a core component of human social life. Individuals who are willing to contribute to joint actions are more likely to cooperate if they are committed. Based on the results, graduates who responded to this study as observed by their supervisors were valuing responsibility by showing their

Table 3. Employers' feedback on performance of the graduates in terms of work attitude.

\begin{tabular}{cccc}
\hline & Item Statements & $\begin{array}{c}\text { Weighted } \\
\text { Mean }\end{array}$ & $\begin{array}{c}\text { Verbal } \\
\text { Interpretation }\end{array}$ \\
\hline 1 & Has a sense of commitment and duty & 3.58 & Exceptional \\
2 & Has an independent functioning capacity & 3.46 & Exceptional \\
3 & $\quad \begin{array}{l}\text { Has the ability to take charge of one's } \\
\text { engagement and empowerment }\end{array}$ & 3.35 & Exceptional \\
4 & $\begin{array}{l}\text { Has the ability to adapt to emerging concepts } \\
\text { and conditions, as well as receptivity to them }\end{array}$ & 3.38 & Exceptional \\
& Average Weighted Mean & 3.44 & Exceptional \\
\hline
\end{tabular}


commitment to work and duty. Job commitment is a factor that leads to employee performance and organizational performance and a concept that should be considered as a factor affecting employee attitudes at the individual level (Özyllmaz \& Süner, 2015) [29]. Furthermore, Paksoy et al. (2017) [30] pointed out that the sense of commitment emanates as a strong emotion that completely seizes the person in vital importance, which is also included in employee profiles that managers target and desire.

Table 4 shows the employer's feedback on the performance of BSBA Marketing Management in terms of communication skills. As presented in the table above, item 3, "Ability to understand printed or written instructions", received the highest weighted mean of 3.46, which is verbally interpreted as "Exceptional". Conversely, item 2, "Capacity to express thoughts articulately", got the lowest weighted mean of 3.31, which was verbally interpreted as "Exceptional". Overall, the employers positively evaluated the performance of the BSBA Marketing Management graduates in terms of communication skills with the average weighted mean of 3.39, which means that they always exceed employers' required standards.

English has become the language of business (Rajwani, 2012 [31]; Sankar \& Kumar, 2016 [32]), and they were able to understand the language of the business world. Understanding instructions is a valuable skill to develop in everyday activities. Data suggested that the employed graduates could follow printed and written directions, which helps establish a professional expectation in the workplace. This is predictable since they were instructed using the English language during their college days. This is a response to the CHED's commitment to internationalization and the use of English as a language of instruction in most higher education programs (Macha et al., 2018) [33]. In addition, Dunham et al., (2020) [34] stated that written instructions are efficient because large amounts of detail can be provided that a person can read rapidly.

Table 5 shows the employers' feedback on the performance of BSBA Marketing Management in terms of numerical competency. As can be observed in the

Table 4. Employers' feedback on performance of the graduates in terms of communication skills.

\begin{tabular}{lccc}
\hline Item Statements & $\begin{array}{c}\text { Weighted } \\
\text { Mean }\end{array}$ & $\begin{array}{c}\text { Verbal } \\
\text { Interpretation }\end{array}$ \\
\hline $1 \quad \begin{array}{c}\text { Ability to write clear and } \\
\text { meaningful communication } \\
2 \quad \text { Capacity to express thoughts articulately } \\
\text { Ability to understand printed } \\
\text { or written instructions } \\
\text { Ability to comprehend oral or } \\
\text { verbal directives from the superior }\end{array}$ & 3.31 & Exceptional \\
Average Weighted Mean & 3.46 & Exceptional \\
\hline
\end{tabular}


Table 5. Employers' feedback on performance of the graduates in terms of numerical competency.

\begin{tabular}{cccc}
\hline Item Statements & $\begin{array}{c}\text { Weighted } \\
\text { Mean }\end{array}$ & $\begin{array}{c}\text { Verbal } \\
\text { Interpretation }\end{array}$ \\
\hline 1 & $\begin{array}{c}\text { Ability to comprehend data } \\
\text { Capacity to use the data to } \\
\text { complete the mission at hand } \\
\text { Average Weighted Mean }\end{array}$ & 3.38 & Exceptional \\
\hline
\end{tabular}

table above, both item 1, "Ability to comprehend data" and item 2, "Capacity to use the data to complete the mission at hand", received the same weighted mean of 3.38, which is verbally interpreted as "Exceptional". Overall, the employers positively evaluated the performance of the BSBA Marketing Management graduates in terms of numerical competency with the average weighted mean of 3.38, which means that they always exceed employers' required standards.

The Business Administration curriculum was well-designed and aligned to help students strengthen their numerical abilities. It is the capacity to deal with numbers to comprehend quantitative concepts and skills related to accuracy and speed in using basic calculation functions so that the better the numerical ability of students (Ozsoy, 2019) [35]. Professional subjects included in CMO 39 series of 2006 under section 12 include Management Accounting, Business Research, Strategic Management, and Production and Operation Management. The majority of these subjects' contents entail computations that enhance the ability of the students to interpret and use numerical data to accomplish the task. Numerical ability is beneficial for students to understand the material, analyze each problem, apply mathematical concepts in everyday life, and not experience difficulties in learning (Ahid et al., 2020) [36].

Table 6 shows the employers' feedback on the performance of BSBA Marketing Management in terms of information technology literacy. As can be derived from the table, item 1, "Ability to adapt to new technologies", received the highest weighted mean of 3.54, which is verbally interpreted as "Exceptional". Meanwhile, item 2, "Ability to maximize the use of the Internet to facilitate work and business", and item 3, "Ability to use technology effectively in the workplace to enhance his job output", respectively got the lowest weighted mean of 3.46, which verbally interpreted as "Exceptional". Overall, the employers positively evaluated the performance of the BSBA Marketing Management graduates in terms of information technology literacy with the average weighted mean of 3.49, which means that they always exceed employers' required standards.

Nowadays, technology plays a vital role in most businesses. Even the traditional business letters and memos, the most common written communication, are now commonly sent through e-mail which requires technology. Moreover, organizations are moving toward a concept known as Electronic Commerce, where transactions are completed via a variety of electronic media, including 
Table 6. Employers' feedback on performance of the graduates in terms of information technology literacy.

\begin{tabular}{|c|c|c|c|}
\hline & Item Statements & $\begin{array}{l}\text { Weighted } \\
\text { Mean }\end{array}$ & $\begin{array}{c}\text { Verbal } \\
\text { Interpretation }\end{array}$ \\
\hline 1 & Ability to adapt to new technologies & 3.54 & Exceptional \\
\hline 2 & $\begin{array}{l}\text { Ability to maximize the use of the } \\
\text { Internet to facilitate work and business }\end{array}$ & 3.46 & Exceptional \\
\hline 3 & $\begin{array}{l}\text { Ability to use technology effectively in } \\
\text { the workplace to enhance his job output }\end{array}$ & 3.46 & Exceptional \\
\hline \multirow[t]{2}{*}{4} & $\begin{array}{l}\text { Ability to locate, gather and organize } \\
\text { information using appropriate technology } \\
\text { and information systems }\end{array}$ & 3.50 & Exceptional \\
\hline & Average Weighted Mean & 3.49 & Exceptional \\
\hline
\end{tabular}

electronic data interchange (EDI), electronic funds transfer (EFT), bar codes, fax, automated voice mail, CD-ROM catalogs, and a variety of others (Moharana et al., 2011) [37]. The data showed that graduates are adaptable to new technologies since most of them belong to Generation $\mathrm{Z}$ or are considered the social generation who have grown up with access to the Internet and portable digital technology from a young age (Kurzu, 2017) [38].

Table 7 shows the employer's feedback on the performance of BSBA Marketing Management in terms of interpersonal skills. Based on the table, item 4, "Can accept and provide feedback in a constructive and considerate manner", received the highest weighted mean of 3.54 , which is verbally interpreted as "Exceptional". On the other hand, item 2, "Ability to continue good intellectual curiosity at work", got the lowest weighted mean of 3.46, which was verbally interpreted as "Exceptional". Overall, the employers positively evaluated the performance of the BSBA Marketing Management graduates in terms of interpersonal skills with the average weighted mean of 3.50, which means that they always exceed employers' required standards.

Learning how to accept and respond to feedback is an integral part of personal and professional development. In the field of education, feedback is described as information regarding the students' performance that is provided to improve their learning (Omer \& Abdularhim, 2017) [39]. The data implied that the graduates brought this outlook in their workplace and showed a good relationship with individuals in the organization. Showing humility on criticism is a positive attitude that is ready to accept changes and cooperate with others. Sarkany and Deitte (2016) [40] cited that although providing constructive feedback can be challenging, it is a learnable skill.

Table 8 shows the employer's feedback on the performance of graduates in terms of recordkeeping skills. As demonstrated in the table above, item 2, "Ability to organize files", received the highest weighted mean of 3.58, which is verbally interpreted as "Exceptional". On the contrary, item 1, "Very eager in 
Table 7. Employers' feedback on performance of the graduates in terms of interpersonal skills.

\begin{tabular}{|c|c|c|c|}
\hline & Item Statements & $\begin{array}{l}\text { Weighted } \\
\text { Mean }\end{array}$ & $\begin{array}{c}\text { Verbal } \\
\text { Interpretation }\end{array}$ \\
\hline 1 & A good team player & 3.50 & Exceptional \\
\hline 2 & $\begin{array}{l}\text { Ability to continue good intellectual } \\
\text { curiosity at work }\end{array}$ & 3.46 & Exceptional \\
\hline 3 & $\begin{array}{l}\text { Ability to appreciate and understand } \\
\text { individual differences in gender, } \\
\text { cultures, and languages at work }\end{array}$ & 3.50 & Exceptional \\
\hline \multirow[t]{2}{*}{4} & $\begin{array}{l}\text { Can accept and provide feedback in a } \\
\text { constructive and considerate manner }\end{array}$ & 3.54 & Exceptional \\
\hline & Average Weighted Mean & 3.50 & Exceptional \\
\hline
\end{tabular}

Table 8. Employers' feedback on performance of the graduates in terms of recordkeeping skills.

\begin{tabular}{|c|c|c|c|}
\hline & Item Statements & $\begin{array}{l}\text { Weighted } \\
\text { Mean }\end{array}$ & $\begin{array}{l}\text { Verbal } \\
\text { Interpretation }\end{array}$ \\
\hline 1 & Very eager in observing procedures at work & 3.35 & Exceptional \\
\hline 2 & Ability to organize files & 3.58 & Exceptional \\
\hline 3 & $\begin{array}{l}\text { Ability to access information by using } \\
\text { appropriate channels and resources }\end{array}$ & 3.38 & Exceptional \\
\hline 4 & $\begin{array}{l}\text { Ability to access information by using } \\
\text { appropriate technologies, channels, and resources }\end{array}$ & 3.38 & Exceptional \\
\hline & Average Weighted Mean & 3.42 & Exceptional \\
\hline
\end{tabular}

observing procedures at work", got the lowest weighted mean of 3.35, which was verbally interpreted as "Exceptional". Overall, the employers positively evaluated the performance of the BSBA Marketing Management graduates in terms of recordkeeping skills with the average weighted mean of 3.42, which means that they always exceed employers' required standards.

Organizing the workplace can boost productivity. According to Wolch, M. (n.d.) [41], locating files easier saves time, resulting in more productivity. The findings revealed that graduates show the art of storing files. This is consistent with the study of Gambill et al. (2008) [42] as mentioned by Kammler (2017) [43], organization crosses all studies for higher education and all life situations where directly teaching organizational skills aids students for their current task (school) while preparing them for their latter jobs (workforce).

Table 9 shows the employers' feedback on the performance of BSBA Marketing Management in terms of technical skills required to do the job. As shown in the table above, item 4, "Able to work to agreed quality standards and specification", received the highest weighted mean of 3.42, which is verbally interpreted as "Exceptional". Meanwhile, item 1, "Ability to handle technical demands in 
Table 9. Employers' feedback on performance of the graduates in terms of technical skills.

\begin{tabular}{|c|c|c|c|}
\hline & Item Statements & $\begin{array}{l}\text { Weighted } \\
\text { Mean }\end{array}$ & $\begin{array}{l}\text { Verbal } \\
\text { Interpretation }\end{array}$ \\
\hline 1 & Ability to handle technical demands in work & 3.31 & Exceptional \\
\hline 2 & Ability to solve technical problems & 3.38 & Exceptional \\
\hline 3 & $\begin{array}{l}\text { Ability to select and use appropriate tools } \\
\text { and technology for a task or project }\end{array}$ & 3.31 & Exceptional \\
\hline 4 & $\begin{array}{l}\text { Able to work to agreed quality standards } \\
\text { and specification }\end{array}$ & 3.42 & Exceptional \\
\hline 5 & $\begin{array}{l}\text { Aware of occupational health and safety } \\
\text { practices and procedures, and act following these }\end{array}$ & 3.35 & Exceptional \\
\hline 6 & $\begin{array}{l}\text { Ability to apply international standards and } \\
\text { practices within discipline or professional area }\end{array}$ & 3.38 & Exceptional \\
\hline & Average Weighted Mean & 3.36 & Exceptional \\
\hline
\end{tabular}

work", and item 3, "Ability to select and use appropriate tools and technology for a task or project", got the lowest weighted mean of 3.31, which verbally interpreted as "Exceptional". Overall, the employers positively evaluated the performance of the BSBA Marketing Management graduates in terms of technical skills with the average weighted mean of 3.36 , which means that they always exceed employers' required standards.

Based on the CHED Memorandum Order 17 series of 2017, Total Quality Management (TQM) is one of the major subjects under the Business Administration Curriculum. The content of this course emphasized the importance of quality in an organization and maintaining high standards and strived for continuous improvement. The findings of this study indicated that the graduates performed their best in this aspect by showing their adaptability, flexibility, skills, and knowledge by following the standard operating procedure of the business, which they might learn in TQM.

\subsection{Employers' Assessment of Competencies of the BSBA Marketing Management Graduates in Relation to the Program Educational Objectives}

Table 10 shows the employer's assessment of competencies of the BSBA Marketing Management graduates in relation to the Program Educational Objectives. As can be observed in the table above, item 2, "Engage in life-long learning activities like graduate studies", received the highest weighted mean of 3.34, which is verbally interpreted as "Strongly Agree". On the other hand, item 1, "Apply the basic concepts, principles, and theories on the difficult situations encountered in the field", got the lowest weighted mean of 3.19, which was verbally interpreted as "Agree". Overall, the employers of the BSBA Marketing Management positively evaluated the competencies of the graduates in relation to the 
Table 10. Employers' assessment of competencies of the graduates in relation to the program educational objectives.

\begin{tabular}{|c|c|c|c|}
\hline & Item Statements & $\begin{array}{l}\text { Weighted } \\
\text { Mean }\end{array}$ & $\begin{array}{c}\text { Verbal } \\
\text { Interpretation }\end{array}$ \\
\hline 1 & $\begin{array}{l}\text { Apply the basic concepts, principles, and theories } \\
\text { on the difficult situations encountered in the field }\end{array}$ & 3.19 & Agree \\
\hline 2 & $\begin{array}{c}\text { Engage in life-long learning activities like } \\
\text { graduate studies }\end{array}$ & 3.34 & Strongly Agree \\
\hline 3 & $\begin{array}{l}\text { Participate in professional services and training } \\
\text { that promote continuous improvement }\end{array}$ & 3.27 & Strongly Agree \\
\hline 4 & $\begin{array}{l}\text { Demonstrate corporate citizenship } \\
\text { and social responsibility }\end{array}$ & 3.31 & Strongly Agree \\
\hline \multirow[t]{2}{*}{5} & Exercise high moral and ethical standards & 3.31 & Strongly Agree \\
\hline & Average Weighted Mean & 3.28 & Strongly Agree \\
\hline
\end{tabular}

Program Educational Objectives with the average weighted mean of 3.28, which means that the graduates were effectively performing their job in accordance with the program educational objectives.

Program educational objectives are the broad statements that describe the career and professional accomplishments that the program is preparing graduates to achieve (Rogers, 2020) [44]. Based on the findings of this study, the graduates were participating in activities that promote continuous learning, like graduate studies which may imply that they give importance to career development. Continuing professional development is essential (King, 2021) [45]. Alsop (2013) [46], said that lifelong learning embraces improvement of knowledge skill and personal competence to participate actively. Pursuing higher education is a lifelong learning process that promotes personal and professional development, which prepares the individuals to be effective within circumstances of their lives and work. Building new skills, acquisition, and application of knowledge can be achieved by continuing to educate oneself, which gives individuals more value and be marketable. This is affirmative with the report of Price et al. (2017) [47], who stated that employees are expected to have sufficient training and education to facilitate workplace transitions and continuing education opportunities throughout their careers for career laddering.

However, it is important to highlight that when it comes to professional graduates' application of fundamental concepts, principles, and theories to difficult situations they experience on the job, the employers are not unanimous in their agreement. This must not be the case since employees' thorough grasp of principles is extremely important and beneficial, especially for managers, because these principles serve as guidelines for managerial operations and should not be neglected. It can avoid various mistakes while dealing with people in the organization. The application of principles in the workplace enables an individual to perform efficiently, collaborate effectively with others, and experience a sense of 
fulfillment because these principles allow them to express themselves freely, participate in decision-making, and feel empowered as individuals who have made significant contribution to the organization (Bacud, 2020) [48].

\subsection{Employers' Likelihood of Hiring Business Administration Graduates from NEUST}

This section presents the feedback from employers concerning their experiences with Business Administration graduates from NEUST who participated in this study, as well as their likelihood of hiring applicants from this university. In general, responses from the industry regarding their impression of the professional graduates were favourable. According to the employers, NEUST graduates were showing excellent performance since they were responsible, easy to train, and willing to learn more about their jobs. They recognized the graduates as highly qualified and highly recommended. As a result, they would be more likely to hire other graduates from the NEUST. Many employers consider job candidates' non-technical competencies associated with one's personality, attitude, and ability to interact effectively with others as critical for professional success as traditional hard skills, especially in today's global marketplace (Stewart, et al. 2016) [49].

\section{Conclusion and Recommendation}

Based on the analysis results, the researchers concluded that most of the graduates of Business Administration-Marketing Management of Nueva Ecija University of Science and Technology San Isidro Campus could find their way to start their careers effectively. Many of the graduates who participated in this study obtained their degree in 2019, worked for more than a year as rank and file, and had a regular status within their organizations.

Based on the assessment of the current employers of the professional graduates, most of them had demonstrated exceptional performance in terms of work attitude, communication skills, numerical competency, interpersonal skills, recordkeeping skills, and technical skills required for the job. They were also engaged in activities that promote lifelong learning, such as graduate studies, since they valued professional advancement. This indicates that the graduates performed their jobs in conformity with the university's educational program objectives.

This study revealed that graduates of the Business Administration program are marketable because they have the necessary skills and knowledge to be competitive to face the challenges of finding a job and becoming part of the workforce. Overall, based on the employers' feedback, the graduates exhibited qualities that consistently exceeded the organizations' standards. It has been manifested that the curriculum was aligned with the norms and principles that satisfy the industry's needs. Thus, their present employers were more likely to hire other business administration graduates from NEUST. 
Despite the positive results of this study, it cannot be overlooked that some graduates are underemployed since they are functioning in positions that do not require a university degree. To minimize unemployment and even underemployment, the researchers proposed that the university focus on integrating educational training with industry and market demands to facilitate access to economic advancement. In this regard, the university can also be requested to take into account a review of the competencies taught to their students and the skills required by the workforce. If a gap does exist, it would be desirable for the university to find it and be more strategic in dealing with it.

At the same time, the researchers recommended broadening the competencies of the graduates, particularly concerning the program's educational objectives. Although it rated a positive response of strongly agree, consideration on the improvement and adaptation of up-to-date teaching methodologies and strategies must be applied. Furthermore, business administration graduates should not be bound by the idea that they are simply supposed to work as employees; instead, they should be exposed to various entrepreneurial activities. As a potential chance for the university to cultivate and nurture its students' innovative thinking skills, this proposal may encourage the business administration graduates to start their own small business instead of searching for employment and working as an employee.

For the present, the university should think about revisiting, revising, and expanding the business administration program curriculum to better prepare their future graduates for the real battlefield after graduation. In relation to this, it is suggested that the university curriculum designing team should be participated by various stakeholders including the employers to ensure quality and relevant course offerings.

In addition to this, the institution should keep an active partnership with the business community to ensure that its students have access to internships and possible job placement after graduation. Likewise, the university may consider requiring its students to take up competencies certification during their stay in the institution to increase their skills competency level which may lead to having a better chance of getting hired not just locally but also globally.

This study, on the other hand, has several limitations that must be considered. For example, the number of responses is one of the factors to consider. Accordingly, it is advised that an increase in the number of information sources is required to cover the enormous pools of employers present in the market. In addition, a focus group discussion can be presented to get more in-depth insights from the business community.

\section{Conflicts of Interest}

The authors declare no conflicts of interest.

\section{References}

[1] Ranasinghe, A. and Herath, H. (2011) Employer Satisfaction towards Business 
Graduates in Sri Lanka. International Conference on Social Science and Humanity, 5, 185-189. http://www.ipedr.com/vol5/no1/39-H00086.pdf

[2] Pasban, M. and Nojedeh, S.H. (2016) A Review of the Role of Human Capital in the Organization. Procedia-Social and Behavioral Sciences, 230, 249-253.

https://doi.org/10.1016/j.sbspro.2016.09.032

[3] Suarez, M.T., Chan, C. and Obieta, J.O.M. (2018) Higher Education Systems and Institutions, Philippines. In: Teixeira, P. and Shin, J., Eds., Encyclopedia of International Higher Education Systems and Institutions, Springer, Dordrecht, 1-25. https://doi.org/10.1007/978-94-017-9553-1_507-1

[4] Sanyal, B.C. (2012) The Role of Higher Education in Obtaining EFA Goals with Particular Focus on Developing Countries (UNESCO Forum on Higher Education, Research \& Knowledge).

https://www.philippinesbasiceducation.us/2012/05/role-of-higher-education.html?f bcl-

id=IwAR0m5qZB-s09S6K4BtxdjDw1r8y0_UMHG3kG-6TAflovhU0kgrsZ8FSv72E

[5] Castano, M.C. and Cabanda, E. (2011) Sources of Efficiency and Productivity Growth in the Philippine State Universities and Colleges: A Non-Parametric Approach. International Business \& Economics Research Journal, 6.

https://doi.org/10.19030/iber.v6i6.3379

[6] Philippine Development Plan 2017-2022 Overall Framework. https://pdp.neda.gov.ph/wp-content/uploads/2017/01/Chapter-4-3292017.pdf

[7] Plantilla, A.M. (2017) Graduates' Performance in the Workplace: Employers' Perspective. Asia Pacific Journal of Multidiciplinary Research, 5, 186-198.

[8] The Institutional Management in Higher Education (2012). https://www.oecd.org/education/imhe/programmeoninstitutionalmanagementinhig hereducationimhe-membertestimonials.htm

[9] Ramirez, T.L., Cruz, L.T. and Alcantara, N.V. (2014) Tracer Study of RTU Graduates: An Analysis. International Refereed Research Journal, 5, 66-76. https://www.academia.edu/14727167/TRACER_STUDY_OF_RTU_GRADUATES_ AN_ANALYSIS

[10] Navarro, L. C. (2020) Workplace Performance of CvSU Naic BSED Graduates: Employers' Feedback. Social Science and Humanities Journal, 4, 2004-2012.

https://www.researchgate.net/publication/344188561_Workplace_Performance_of_ CvSU_Naic_BSED_Graduates_Employers'_Feedback

[11] Encio, H.A., Buenviaje, M.G., Refozar, R.F. and Laguador, J.M. (2016) Employers' Feedback on the Competencies of MBA Graduates Based on Curriculum and Student Outcomes. IOSR Journal of Business and Management, 18, 101-105. https://doi.org/10.9790/487X-180804101105

[12] Al-Kassem, A.H. (2017) Recruitment and Selection Practices in Business Process Outsourcing Industry. Archives of Business Research, 5, 40-52.

https://doi.org/10.14738/abr.53.2180

[13] Burning Glass Technology (2015) The Human Factor the Hard Time Employers Have Finding Soft Skills Burning Glass Technologies.

https://www.burning-glass.com/wp-content/uploads/Human_Factor_Baseline_Skill s_FINAL.pdf

[14] Mourshed, M., Farrell, D. and Barton, D. (2012) Education to Employment: Designing a System That Works. McKinsey Center for Government.

[15] Cooper, D.R. and Schindler, P.S. (2011) Business Research Methods. McGraw-Hill, New York. 
[16] Parker, C., Scott, S. and Geddes, A. (2019) Snowball Sampling. SAGE Research Methods Foundations.

http://eprints.glos.ac.uk/6781/1/6781\%20Parker\%20and\%20Scott\%20\%282019\%29 \%20Snowball\%20Sampling_Peer\%20reviewed\%20pre-copy\%20edited\%20version.p df

[17] Sannadan, J.G.M., Langay, P.L.D. and Guidangen, J.S. (2016) Feedback of Employers on the Performance of Ba-History Graduates of KASC. International Journal of Advanced Research in Management and Social Sciences, 5, 220-231.

https://www.researchgate.net/publication/294085485_FEEDBACK_OF_EMPLOYE RS_ON_THE_PERFORMANCE_OF_BA-HISTORY_GRADUATES_OF_KASC

[18] Commission on Higher Education (2017) CHED K to 12 Transition Program. CHED. https://ched.gov.ph/k-12-project-management-unit

[19] De Guzman, N.F.P. (2017) K-12: Transition and Transformation-BusinessWorld. Webblog. https://www.bworldonline.com/k-12-transition-and-transformation

[20] Dhaliwal, R.S. and Misra, P. (2020) Employability Skills Needed in Hospitality Industry: A Scopious Review. Asian Journal of Education and Social Studies, 10, 18-34. https://doi.org/10.9734/ajess/2020/v10i130258

[21] Adiyoh, I.S., Ze, T., Tougem, T.O. and Dalibi, S.G. (2020) Effect of COVID-19 Pandemic on Small and Medium Scale Businesses in Nigeria. International Journal of Research Publications, 56, 122-129. https://doi.org/10.47119/IJRP100561720201305

[22] Lim, J.A. (2020) The Philippine Economy During the COVID Pandemic. Ateneo Center for Economic Research and Development.

https://ateneo.edu/sites/default/files/downloadable-files/ADMU\%20WP\%202020-1 6.pdf

[23] Bhattacharjee, P. (2020) Attitude of College Students towards Entrepreneurship of Nagaon Town in Assam. International Journal of Advanced Research in Engineering and Technology (IJARET), 11, 11-12.

[24] De Leon, C.L., Vitug, E.G., Mina, J.C., Vega, N.C., Barlis, P.T., Galano, J.A., Caymo, E.S. and Flores, R.B. (2020) Entrepreneurial Access of Entrepreneurship Graduates: A Basis for the Evolution of Financing Young Entrepreneurs. Change Management Journal, 185, 1-19. https://www.brightlinkresearchindex.org/journals/view/86

[25] Deluna, R. and Berdos, K. (2015) Factors Affecting Length of Job Search and Job Switching in Davao City, Philippines. Munich Personal RePEc Archive.

https://mpra.ub.uni-muenchen.de/68802/1/MPRA_paper_68802.pdf

[26] Berry (2018) Federal Employee Probationary Employee Rights. Federal Employee Law Blog. https://federalemployeelawblog.com/2018/02/04/federal-employee-probationary-e $\underline{\text { mployee-rights }}$

[27] Vardi, Y. and Hammer, T.H. (2017) Intraorganizational Mobility and Career Perceptions among Rank and File Employees in Different Technologies. Academy of Management Journal, 20, 622-634. https://doi.org/10.5465/255361

[28] Claussen, J., Grohsjean, T., Luger, J. and Probst, G. (2014) Talent Management and Career Development: What It Takes to Get Promoted. Journal of World Business, 49, 236-244. https://doi.org/10.1016/j.jwb.2013.11.007

[29] Özyılmaz, A. and Süner, Z. (2015) The Effect of Job Engagement on Job Attitudes: Results of Empirical Research Conducted in 9 Business Organizations in Hatay.

[30] Paksoy, M., Soyer, F. and Calik, F. (2017) The Impact of Managerial Communication Skills on the Levels of Job Satisfaction and Job Commitment. Journal of Human 
Sciences, 14, 642. https://doi.org/10.14687/jhs.v14i1.4259 https://www.j-humansciences.com/ojs/index.php/IJHS/article/view/4259/2131

[31] Rajwani, H.G. (2012) English as a Tool of Empowerment for Employability Entrepreneurial Opportunity and Impact of Large Scale Projects in English Education on Employability. International Multidisciplinary e-Journal, 1, 37.

http://www.shreeprakashan.com/documents/2012927155635846.8.heera\%20g.\%20r ajwani.pdf

[32] Sankar, G. and Kumar, S.P.S. (2016) English for Employability and Empowerment: A Study. Academic Research Journals, 4, 100-103.

https://www.academicresearchjournals.org/IJELC/PDF/2016/July/Sankar\%20and\%2 0Kumar.pdf

[33] Macha, W., Mackie, C. and Magaziner, J. (2021) Education in the Philippines. WENR. https://wenr.wes.org/2018/03/education-in-the-philippines

[34] Dunham, S., Lee, E. and Persky, A.M. (2020) The Psychology of Following Instructions and Its Implications. American Journal of Pharmaceutical Education, 84, ajpe7779. https://doi.org/10.5688/ajpe7779

[35] Ozsoy, Y. (2019) A General View to the Academic Journals in the Field of Gifted Education in Turkey. Journal of Gifted Education and Creativity, 6, 40-53.

[36] Ahid, N., Haspani, N., Cahyadi, R., Faelasofi, R., Pertiwi, S., Ganda Putra, F. and Jermsittiparset, K. (2020) Numerical Skills Analysis Gifted Young scientists: The Impact of the Team Assisted Individualization (TAI) Learning Model. Journal for the Education of Gifted Young Scientists, 8, 47-59.

https://doi.org/10.17478/jegys.665117

[37] Moharana, H.S., Murty, J.S., Senapati, S.K. and Khuntia, K. (2011) Importance of Information Technology for Effective Supply Chain Management. International Journal of Modern Engineering Research, 1, 147-151. https://www.ijmer.com/pages/vol1-issue2.html

[38] Kurzu, J. (2017) Generation Z: The Lasting Influence of the Digital Native on Marketing. https://shareok.org/bitstream/handle/11244/317237/oksd_kurzu_HT_2017.pdf?seq uence $=1$ \&isAllowed $=\mathrm{y}$

[39] Omer, A.A.A.A. and Abdularhim, M.E. (2017) The Criteria of Constructive Feedback: The Feedback That Counts. Journal of Health Specialties, 5, 45. https://doi.org/10.4103/2468-6360.198798

[40] Sarkany, D. and Deitte, L. (2017) Providing Feedback. Academic Radiology, 24, 740-746. https://doi.org/10.1016/j.acra.2016.11.023

[41] Wolch, M. (n.d.) Benefits of Keeping Organized at Work. Monster Career Advice. https://www.monster.ca/career-advice/article/benefits-of-keeping-organized-at-work

[42] Gambill, J.M., Moss, L.A. and Vescogni, C.D. (2008) The Impact of Study Skills and Organizational Methods on Student Achievement. https://files.eric.ed.gov/fulltext/ED501312.pdf

[43] Kammler, A. (2017) An Organized Student Is a Successful Student. Parent Today, Capital Region BOCES Communications Service, Albany. https://www.parenttoday.org/an-organized-student-is-a-successful-student

[44] Rogers, G. (2020) Program Educational Objectives and Student Outcomes: Same But Different. ABET.

https://www.abet.org/wp-content/uploads/2020/09/Objectives_Outcomes-09.09.20. pdf

[45] King, R., Taylor, B., Talpur, A., Jackson, C., Manley, K., Ashby, N., Tod, A., Ryan, 
T., Wood, E., Senek, M. and Robertson, S. (2021) Factors That Optimise the Impact of Continuing Professional Development in Nursing: A Rapid Evidence Review. Nurse Education Today, 98, Article ID: 104652.

https://doi.org/10.1016/j.nedt.2020.104652

[46] Alsop, A. (2013) Lifelong Learning and Continuing Professional Development. In: Continuing Professional Development in Health and Social Care: Strategies for Lifelong Learning, Second Edition, John Wiley \& Sons, Ltd., Hoboken, 1-11. https://doi.org/10.1002/9781118782859.ch1

[47] Price, S. and Reichert, C. (2017) The Importance of Continuing Professional Development to Career Satisfaction and Patient Care: Meeting the Needs of Novice to Mid- to Late-Career Nurses throughout Their Career Span. Administrative Sciences, 7, 17. https://doi.org/10.3390/admsci7020017

[48] Bacud, S.A.D. (2020) Henri Fayol's Principles of Management and Its Effect to Organizational Leadership and Governance. Journal of Critical Reviews, 7, 162-167. https://doi.org/10.31838/jcr.07.11.25

[49] Stewart, C., Wall, A. and Marciniec, S. (2016) Mixed Signals: Do College Graduates Have the Soft Skills That Employers Want? American Society for Competitiveness. https://www.researchgate.net/publication/316066488_Mixed_Signals_Do_College_ Graduates_Have_the_Soft_Skills_That_Employers_Want 